\title{
sciendo \\ THE MARKET FUNCTIONING OF POLISH HIGHER EDUCATION INSTITUTIONS IN THE CONTEXT OF THE IMPLEMENTATION OF THE CONCEPT OF SOCIAL RESPONSIBILITY
}

\author{
RYNKOWE FUNKCJONOWANIE POLSKICH UCZELNI \\ W KONTEKŚCIE REALIZACJI KONCEPCJI SPOŁECZNEJ ODPOWIEDZIALNOŚCI
}

Angelika M. Pabian (PhD)

University of Silesia in Katowice

Ul. Bankowa 11, 40-007 Katowice

angelika.pabian@us.edu.pl • ORCID 0000-0002-8958-4262

DOl: 10.2478/minib-2021-0001

\section{ABSTRACT}

The evolution in the sector set new tasks for Higher Education Institutions (HEls) ${ }^{*}$, where - in addition to educational activity - their cooperation with other entities is assumed, which will make it possible to take up contemporary challenges. One of these is University Social Responsibility (USR)*, the popularity of which is growing; however, this area is not sufficiently recognized in the relevant literature. This fact was an important premise for undertaking research to assess the current state of the higher education sector in the context of the implementation of the concept of social responsibility. The purpose of the paper is to show students' opinions on the implementation of USR by HEls and their knowledge of SR. The author's intention is to present the results of her own research. The material obtained in the course of the survey showed that the symptoms of the adaptation of the concept of Social Responsibility $(\mathrm{SR})^{*}$ to $\mathrm{HEl}$ management were identified, but the degree of their involvement in this area is insufficient, as is the level of students' knowledge in the field of SR. The exploratory research referred to in this article is an introduction to a broader scope of research.

Key words: CSR; SR; USR; Declaration of University Social Responsibility; academic values; market orientation of the higher education sector. 


\section{ABSTRAKT}

Ewolucja dokonana w sektorze wyznaczyła nowe zadania uczelniom, gdzie oprócz działalności kształceniowej, zakłada się ich wspótpracę z pozostałymi podmiotami, dzięki czemu możliwe ma stać się podejmowanie współczesnych wyzwań. Jednym z nich jest społeczna odpowiedzialność uczelni (USR), której popularność rośnie, jednak w literaturze przedmiotu obszar ten nie jest dostatecznie zdiagnozowany. Fakt ten stanowił istotną przesłankę do podjęcia wysitków badawczych celem oceny aktualnego stanu sektora szkolnictwa wyższego w kontekście wdrażania i realizacji koncepcji społecznej odpowiedzialności. Celem artykułu jest przedstawienie opinii studentów na temat wdrażania koncepcji USR oraz ich wiedzy w zakresie SR. Zamierzeniem Autorki jest przedstawienie wyników badań własnych. Uzyskany w toku ankietyzacji materiał pozwolił na diagnozę, w ramach której okazało się, iż identyfikowane są symptomy adaptacji koncepcji SR do zarządzania uczelniami, jednak poziom ich zaangażowania jest w tym obszarze niewystarczający, podobnie jak poziom wiedzy studentów w zakresie SR. Badanie eksploracyjne referowane w niniejszym artykule stanowi wstęp do badań o szerszym zakresie.

Słowa kluczowe: CSR; SR; USR; Deklaracja społecznej odpowiedzialności uczelni; wartości akademickie; orientacja rynkowa szkół wyższych

JEL: M14, I23, M31

\section{Introduction}

Community academic culture, which is a derivative of centuries-old university tradition, clashed with corporate culture, which was considered to be inconsistent with the mission of the university in the early stages of the evolution of the higher education market. L. Giuffre and S.E. Ratto claim that the modern university is characterized by contradiction, and its essence is based on pairs of acronyms such as tradition-innovation, stagnation-renewal, and statism-dynamism (Giuffre, Ratto, 2014).

Evolution in the higher education sector in Poland in the 1990s was particularly visible due to the growing number of higher education institutions and also qualitative changes in the university management sphere. However, as it turned out, enthusiasts of implementing business 
solutions for HEI management made every effort to ensure that the peculiar revolution experienced by higher education was not a process of the degradation of the ethos of the academic environment, but translated into the increased quality of education, matching the skills, knowledge and competences of graduates to the needs of the labor market, as well as rationalizing science, understood as its pragmatic use.

"Educational institutions have a special place in society and provide services related to the transfer of knowledge to their customers individuals, public and private organizations and society in general. Their development is influenced by various factors linked to political, technological, economic, environmental, and social trends and changes" (Gourova, Todorova, Gourov, 2009).

The changeability of the environment, including the slowing trend of the mass desire to educate as reported by potential students and the accompanying continuous increase in the number of HEIs (mainly nonpublic ones), intensified by competitive mechanisms on the European market, are an excellent confirmation of the thesis that managing HEI resources in the conditions of the turbulent environment is a necessary process, not so much to gain a competitive advantage as to survive. HEIs have turned resource administration and complying with top-down directives into conscious management, which required undertaking activities in the field of the diversification of sources of financing statutory activities and stimulation in the area of promotion of educational and research services, as well as the active recruitment of students. The future of HEIs depends to a large extent on the precise development of the strategy. It is therefore necessary to define the actions that will allow for adaptation to external conditions. Strategic planning enabling the HEI to be viewed from a broad perspective was a natural consequence of this. It meant the need to develop strategic solutions, taking into account the goals of the HEI and its resources, and then implementing the strategy.

The purpose of the research referred to in the article was to identify the determinants of the implementation of a concept of social responsibility by HEIs in two aspects. The first aspect is the optics of the HEI's market operation (not strictly related to the didactic process), while the second one is related to the HEI's obligation to shape the knowledge society, acting with a level of awareness in the area of consumption and sustainable 
development. The study was conducted among students at HEIs located in the south of Poland (Silesia and the surrounding area). The reason for the research was, among others, the fact that HEIs signed the Declaration of University Social Responsibility on 16 November 2017 and 17 September 2019 (KRASP, 2019).

\section{Literature Review}

The literature is rich in various definitions of social responsibility. An overview of the definitions in chronological order is given in Table 1.

The origins of many definitions of corporate social responsibility can be also found in the European Commission's definition formula (A renewed EU strategy 2011-14 for corporate social responsibility), which states that the keys to CSR policy are many documents that regulate the standard of $\mathrm{SR}^{* *}$. The mentioned documents discuss the essence of CSR, which not only applies to business, e.g. The Green Paper (2001) and WHITE PAPER ON THE FUTURE OF EUROPE (2017) that are the basis for determining a strategic role for higher education.

The criticized market orientation of the HEI, has now become fact. In light of research conducted by A.M. Pabian in 2014, Polish HEIs professionalize management which is evidenced by the results obtained according to the level of market orientation (Pabian, 2016). The source material obtained indicates that academic and market cultures do not have to be in opposition to each other, which is especially visible in the process of implementing the concept of social responsibility of the HEI, i.e. University Social Responsibility (USR). The latter is understood as: "the ability of the University to disseminate and implement a set of general principles and specific values, using four key processes: Management, Teaching, Research and Extension, through the provision of educational services and transfer knowledge following ethical principles, good governance, respect for the environment, social engagement and the promotion of values" (Giuffre, Ratto, 2014). 


\section{Table 1. CSR Definitions in different decades}

\begin{tabular}{|c|c|c|c|c|}
\hline Author & $\begin{array}{l}\text { Definition in the } \\
\text { chronological order }\end{array}$ & \multicolumn{2}{|c|}{$\begin{array}{l}\text { Type of CSR by } \\
\text { W.C. Frederick }\end{array}$} & $\begin{array}{l}\text { Summary } \\
\text { of dimensions }\end{array}$ \\
\hline \multirow[t]{4}{*}{ J.W. McGuire, (1963) } & \multirow{4}{*}{$\begin{array}{l}\text { "The firm has not only economic and } \\
\text { legal obligations, but also certain } \\
\text { responsibilities to society which extend } \\
\text { beyond these obligations." }\end{array}$} & \multicolumn{2}{|c|}{ 1950s-mid-1970s } & $1950 \mathrm{~s}-1960 \mathrm{~s}$ \\
\hline & & \multirow{3}{*}{\multicolumn{2}{|c|}{$\begin{array}{l}\text { "CSR } \text { (Corporate Social Responsibility) follows the }_{\text {trend of the early renditions of CSR (Bowen, 1953). }} \text { According to Frederick, the fundamental idea } \\
\text { embedded in CSR is that business corporations } \\
\text { have an obligation to work for social betterment } \\
\text { (Frederick, 1978, 1994). This may be a voluntary } \\
\text { or legal obligation, and dominates over profits." }\end{array}$}} & Philanthropy \\
\hline & & & & $1970 \mathrm{~s}-1980 \mathrm{~s}$ \\
\hline & & & & \\
\hline \multirow[t]{2}{*}{ A.B. Carroll (1979) } & \multirow{2}{*}{$\begin{array}{l}\text { "Social Responsibility of business: } \\
\text { encompasses the economic, legal, ethical, } \\
\text { and discretionary expectations that } \\
\text { society has of organizations at a given } \\
\text { point in time." }\end{array}$} & \multicolumn{2}{|c|}{$1970 \mathrm{~s}-1980 \mathrm{~s}$} & \\
\hline & & \multicolumn{2}{|c|}{$\begin{array}{l}\text { "CSR } \text { (Corporate Social Responsiveness) refers } \\
\text { to a corporation's capacity to respond to social } \\
\text { pressures. [...] } \mathrm{CSR}_{2} \text { is a practically-oriented } \\
\text { approach emphasising the management } \\
\text { of a company's relations with society and } \\
\text { it focuses on the long-run role of the company } \\
\text { in a dynamic social system." }\end{array}$} & Regulated CSR \\
\hline \multirow[t]{2}{*}{ M. Hopkins (1998) } & \multirow[b]{2}{*}{$\begin{array}{l}\text { Corporate Social } \\
\text { Responsibility/Sustainability (CSR) } \\
\text { is a process that is concerned with } \\
\text { treating the key stakeholders } \\
\text { of a company or institution ethically } \\
\text { or in a responsible manner. Éthically } \\
\text { or Responsibly means treating the key } \\
\text { stakeholders, and being treated by them, } \\
\text { in a manner deemed acceptable according } \\
\text { to international norms. }\end{array}$} & \multirow{5}{*}{$\begin{array}{l}\text { 1986-present } \\
\\
\text { Rectitude) which } \\
\text { supposes that } \\
\text { "embedded within } \\
\text { humankind are moral } \\
\text { meanings and } \\
\text { conceptions of what } \\
\text { is felt to be ethical". } \\
\text { CSR }{ }_{3} \text { was proposed } \\
\text { to fill the "value" gap } \\
\text { in CSR } 1 \text { and CSR } \\
\text {. }\end{array}$} & 1998-present & 1990 s-present \\
\hline & & & \multirow{4}{*}{$\begin{array}{l}\text { "CSR } \text { (Corporate Social } \\
\text { Reason) relates to issues } \\
\text { of the Cosmos, Science } \\
\text { and Religion - a } \\
\text { paradigm shift to focus } \\
\text { our attention on the } \\
\text { substantive content of } \\
\text { CSR, instead of getting } \\
\text { stuck in the "CSR trap" } \\
\text { as in } \mathrm{CSR}_{1} \text {, CSR } 2 \\
\text { and CSR } \\
\text { our which trains } \\
\text { on the Corporation." }\end{array}$} & \multirow{4}{*}{$\begin{array}{l}\text { Instrumental/Strategic } \\
\text { CSR }\end{array}$} \\
\hline $\begin{array}{l}\text { World Business } \\
\text { Council for } \\
\text { Sustainable } \\
\text { Development (2001) }\end{array}$ & $\begin{array}{l}\text { "CSR is the continuing commitment } \\
\text { by business to behave ethically and } \\
\text { contribute to economic developments } \\
\text { while improving the quality of life of the } \\
\text { workforce and their families as well } \\
\text { as the local community and society at large." }\end{array}$ & & & \\
\hline $\begin{array}{l}\text { Commission } \\
\text { of the European } \\
\text { Communities (2001) }\end{array}$ & $\begin{array}{l}\text { Corporate social responsibility is } \\
\text { essentially a concept whereby companies } \\
\text { decide voluntarily to contribute to } \\
\text { a better society and a cleaner } \\
\text { environment. }\end{array}$ & & & \\
\hline $\begin{array}{l}\text { D.A. Whetten, } \\
\text { G. Rands, } \\
\text { P. Godfrey (2002) }\end{array}$ & $\begin{array}{l}\text { "societal expectations of corporate } \\
\text { behaviour; a behaviour that is alleged } \\
\text { by a stakeholder to be expected by society } \\
\text { or morally required and is therefore } \\
\text { justifiably demanded of a business." }\end{array}$ & & & \\
\hline
\end{tabular}

Source: own study based on (Cornelius, Wallace, Tassabehji, 2007; Carroll, 1976; Crowther, Aras, 2008; Dahlsrud, 2008;

Tien, 2014; https://www.csrfi.com/hopkinscsrmodel; Hamidu, Haron, Amran, 2015). 
An attempt to define the concept of USR was made by J. Reiser. In his opinion, USR is "a policy of ethical quality of the performance of the university community (students, faculty and administrative employees) via the responsible management of the educational, cognitive, labor and environmental impacts produced by the university, in an interactive dialogue with society to promote a sustainable human development" (Vasilescu, Barna, Epure, Baicu, 2010). In addition to this oft-quoted definition, it is also worth mentioning one more, formulated at the University-Community Engagement Conference in 2009: "an ethical approach to develop a sense of civic citizenship and socially responsible students, academic staffs and faculty members in other to promote social, ecological, environmental, technical and economical engagement for a long lasting and sustainable local and global community" (Sawasdikosol, 2009). The definitions provided above seem to correspond perfectly with HEI activities as a result of the mission assigned to the academic units of the higher education sector.

HEIs are considered the centers of intelligence, knowledge and creative activity, and they also play an important role in scientific, cultural, social and economic development, as reflected in the USR levels promoted by L. Tetřevová and V. Sabolová. ( Tetřevová, Sabolová, 2010). The great capacity of the CSR conceptual construct is highlighted by S.A. Alzyoud and K. Bani-Ani. In their opinion, USR consists of many areas, including "the need to strengthen civil commitment and active citizenship; to provide services to the community through community engagement and outreach; to promote economic and national development; to promote ethical approaches to issues; to develop a sense of civil citizenship by encouraging the students and the academic and administrative staff to provide social services to their local community; to promote ecological or environmental commitment for local and global sustainable development; to develop local and global human resources; to expand human knowledge through quality research and education for the nation and for humanity" (Alzyoud, Bani-Hani, 2015).

The main goal of the implementation of USR by HEIs is to have a positive impact on society in the areas of education, ethics, ecology, in the economic and legal or philanthropic spheres affecting both local and global sustainable development. It is worth emphasizing the fact that the 
responsibility for improving the concept of SR lies with both HEIs and stakeholders, with whom it has various systems of connections. The issue of shared responsibility is emphasized by F. Vallaeys, who sees the opportunity "to find mutually beneficial solutions to build value for all social actors [...], rather than creating value for some at the expense of others" (Vallaeys, 2018).

Document that confirms the growing interest of the academic community in social responsibility is the "Universities for Enlightenment" Declaration" (online 2019). On 13 December 2018, a meeting of the Presidents of the Conference of Rectors of 10 Central European countries (the representatives of the Conference of Rectors of Austria, Croatia, the Czech Republic, Germany, Italy, Poland, Slovakia, Slovenia, and Switzerland) took place in Vienna, where the role of modern universities in society was discussed. The signed declaration indicates the threats to elementary values underlying democratic society, and it determines the responsibility of HEIs in the area of shaping these values in both the student environment and in society (Buchat, Jakubiak, Skiert, Wilczeewski, 2018).

Furthermore, HEI documents include those that confirm the acceptance of social responsibility. These include HEI strategies, as well as documents describing HEI quality assurance systems or, finally, codes of ethics of students and research and teaching staff. These documents are tools that allow for the practical implementation of the concept of USR. A set of ethical responsibilities arising from the rights and duties of students and lecturers translates into the quality of the educational process, which HEIs additionally specify in documents. Due to challenges faced by HEIs related to the growing social requirements for a deep dialogue between HEIs and stakeholders (Deklaracja społecznej odpowiedzialności uczelni), they also had an impact on the above-mentioned quality assurance system. Curricula, including student apprenticeship systems and the ways of evaluating the obtained learning outcomes, are increasingly the result of cooperation between the representatives of the academic community and labor market representatives. The latter, as HEI beneficiaries, constitute an advisory body which helps HEIs offer a product fully adapted to the requirements of the market economy and the knowledge-based economy. The Code of Good Practices in Higher Education Institutions (2007), which 
was drawn up by the Foundation of Polish Rectors, is an expression of the understanding of the academic community regarding the issue of social responsibility (KRASP, 2019).

Another national document regarding USR is the Declaration of University Social Responsibility with 12 principles. In 2017, 23 public and non-public HEIs decided to sign the declaration. The document is "the voluntary commitment of HEIs to promoting the idea of sustainable development and social responsibility in curricula, scientific research as well as management and organizational solutions" (Universities for Enlightenment). The signatories of the document are guaranteed the following benefits: cooperation with government administration, the development of the network of partnerships and cooperation of the academic community, shaping new ideas and ethical values, building the position of the leader of changes in the academic environment, and spreading good HEI practices. On 17 September 2019 during a ceremony at which the list of Declaration members was expanded, 60 more HEIs signed the document.

Despite the growing number of documents created in order to properly implement the concept of social responsibility, it is difficult to clearly determine what stage of development USR is at. Within the group of 397 HEIs in Poland, their various levels of advancement are identified within various trends (directions) of social responsibility. After a stage characterized by the complete lack of interest of the academic community in management concepts (including USR) or even the reluctance to draw on the experience of the business sphere, it can be stated that some HEIs have changed their position. 83 HEIs decided to sign the Declaration of University Social Responsibility, which may be evidence of an attitude of social obligation, a sense of responsibility or an attitude of social reaction.

Different countries represent different levels of social and economic development, including in the higher education sector. The degree of state interference in higher education and the level of market orientation of HEIs are an important reason to choose a sub-area of interest within the framework of USR. This is perfectly illustrated by the results of research projects conducted by scientists around the world from different perspectives $* * *$. 


\section{Materials and Methods}

The research project entitled The market functioning of the HEI in the context of implementing the concept of USR is a continuation of the author's scientific interests in HEI management and was financed from the author's own funds. The main research was conducted from March 2019 to May 2019.

The purpose of the planned and conducted research was to identify the determinants of the implementation of the concept of social responsibility by HEIs both in the context of the market functioning of HEIs (not strictly pertaining to the educational process), and in the context of the obligation voluntarily accepted by HEIs to shape the knowledge society, being aware in the area of consumption and sustainable development. The research objectives corresponded to couple modules of the research process respectively.

The selection of respondents was done using judgmental sampling (socalled arbitrary sampling) belonging to the group of non-probability sampling methods. It is based on the researcher's intuition, experience and knowledge. In this form, a researcher chooses a sample according to predetermined criteria that, in his or her opinion, may determine the expected quantity and reliability of information (Ibom, Akpan, 2014). Considering all limitations of the procedure used (i.e. sample representativeness is difficult to determine and lower than in the case of random samples), the lack of the sampling frame of the study population determined the choice of the sample selection method.

The sampling was based on the assumption that the structure of the group of respondents in terms of the features analyzed (such as gender and field of study) will correspond to the structure of the general population. It is worth adding that in the process of sample selection, care was taken to maintain typological representativeness regarding the declared field of education, which in practice consisted of a selection of population representatives such that all values of the variable identified in the general population would be reflected in the research.

The intention to conduct research was determined by the current situation in the higher education sector, the significant level of market 
orientation of Polish HEIs and the activity of the academic community in the area of social responsibility. Research was embedded in a cognitive perspective, which resulted in recognizing the image of modern HEIs in the eyes of students and identifying the degree of advancement of education in the field of social responsibility. The research results will contribute to further explorations related to factors which determine the identified reality of HEI functioning and the level of knowledge of students. The author's scientific intentions focused on filling the cognitive gap in the field of USR, which has not yet been sufficiently identified in Poland, as evidenced by the limited number of research projects on this subject and reports on the implementation of the concept of USR. E. Pędziwiatr, A. Czaplicka-Kotas and J. Kulczycka (2018) pointed out that no Polish technical universities prepared a report on social responsibility (data for 2018); however, the authors see the possibility of change in this area due to the Declaration of University Social Responsibility reporting on USR. As a result, in the reported research, the focus was on finding the answer to the question: how is it?, and thus the project had the features of exploratory research. The nature of the research was an important factor which determined the power (significance) of hypotheses that concerned the existence of phenomena and states of affairs and their level — the so-called weak level of significance of hypotheses.

In the study, the survey method was used, taking into account circumstances that indicate that it is currently most popular among researchers and respondents. In turn, the lack of access to a list of students including e.g. e-mail addresses influenced the choice of the traditional (paper) form of the survey. The study consisted of handing out the survey form to the respondent, who completed and returned it to the interviewer. Its undoubted advantage is the possibility of sample control and high return rate. The primary limitation is the resistance of respondents to all kinds of surveys, which are perceived as time-consuming. The study costs are relatively high, which is associated with the complexity of the study process and the need to have a team of interviewers who must be properly trained (Babbie, 1990).

The data was obtained on the basis of the author's original survey questionnaire, which corresponds to the research assumptions, so the form was divided into several parts corresponding to the research modules. 


\section{Results}

The survey involved 162 respondents studying around Silesia regardless of nationality

(Table 2) who were asked to complete survey questionnaires. Research took place on academic campuses due to the fact that it was the easiest way to collect samples. It is necessary to emphasize that the study, due to the size of the sample, was only illustrative and was intended as an introduction to further, more structured studies, carried out on a larger sample.

\section{Table 2. Characteristics of the respondents (\%)}

\begin{tabular}{|c|c|c|c|c|c|c|c|}
\hline \multicolumn{8}{|c|}{ Detailed list } \\
\hline \multicolumn{8}{|c|}{ Sex } \\
\hline \multicolumn{4}{|c|}{ Women } & \multicolumn{3}{|c|}{ Men } & Comments \\
\hline \multicolumn{3}{|c|}{60,5} & \multicolumn{4}{|c|}{39,5} & $\begin{array}{l}\text { The structure of the respondents } \\
\text { in terms of the analyzed feature was } \\
\text { similar to the one identified in the } \\
\text { general population }\end{array}$ \\
\hline \multicolumn{8}{|c|}{ Age } \\
\hline 18-25 & 26-30 & 31-40 & 41-50 & $51-60$ & 61-70 & 71 and more & \multirow{2}{*}{$\begin{array}{l}96,3 \% \text { of the respondents were } \\
\text { between } 19-25 \text { years old, so they were } \\
\text { people at the age typical of higher } \\
\text { education in Poland }\end{array}$} \\
\hline 96,3 & 3,7 & - & - & - & - & - & \\
\hline \multicolumn{8}{|c|}{ Fields of education } \\
\hline \multicolumn{4}{|c|}{ Business and administration subgroup } & \multicolumn{3}{|c|}{51,9} & \multirow{7}{*}{$\begin{array}{l}\text { Two fields of study (medical and } \\
\text { pedagogical) were underrepresented } \\
\text { in the sample }\end{array}$} \\
\hline \multirow{2}{*}{\multicolumn{4}{|c|}{$\begin{array}{l}\text { Engineering and technical subgroup } \\
\text { Medical subgroup }\end{array}$}} & \multicolumn{3}{|c|}{8,6} & \\
\hline & & & & \multicolumn{3}{|c|}{3,1} & \\
\hline \multicolumn{4}{|c|}{ Social subgroup } & \multicolumn{3}{|c|}{11,7} & \\
\hline \multicolumn{4}{|c|}{ Pedagogical subgroup } & \multicolumn{3}{|c|}{4,9} & \\
\hline \multicolumn{4}{|c|}{ Language subgroup } & \multicolumn{3}{|c|}{8,6} & \\
\hline \multicolumn{4}{|c|}{ Others } & \multicolumn{3}{|c|}{11,1} & \\
\hline
\end{tabular}

Source: own study. 
Assuming that, in the case of a group of students, it will be easier to choose the activities conducted by their HEI, it will be more difficult to determine the level of HEI involvement in SR issues. This state of affairs determined the order in which questions were asked. The most common choice of respondents was low and medium degrees of involvement in the implementation of the concept of SR (Table 3). In total, nearly $58 \%$ of the respondents made such judgments (details on the degree of implementation of the USR concept perceived by students are presented in the study by A.M. Pabian, 2019). Summing up, it should be emphasized that the degree of implementation of the USR concept is, in the opinion of the respondents, unsatisfactory according to the adopted scale.

\section{Table 3. Degree of HEl involvement in the implementation of the concept of SR} in the opinion of students

\begin{tabular}{c|c|c|c}
\hline Rating & Degree of HEI involvementassigned to the rating & N & Percent \\
\hline 0 & no involvement & 11 & 6.8 \\
1 & negligible involvement & 31 & 19.1 \\
2 & low involvement & 49 & 30.2 \\
3 & medium involvement & 44 & 27.2 \\
4 & high involvement & 25 & 15.4 \\
5 & very high involvement & 2 & 1.2 \\
\hline
\end{tabular}

KEY:

a rating of 4-5 - satisfactory degree of HEI involvement in the implementation of the concept of SR; a rating of 2-3 - unsatisfactory degree of HEI involvement in the implementation of the concept of SR; a rating of $0-1-$ undesirable degree of HEI involvement in the implementation of the concept of SR.

Source: own study.

The degree of insufficient awareness of students in the area of social responsibility of both business entities and non-profit organizations anticipated before the study was a factor in determining the research effort, consisting of identifying the level of students' knowledge of the leading subject of the research. In this part of the survey, several tasks were assigned to the respondents. The first consisted of assessing their level of development in several areas regarding knowledge, the degree of sensitivity and tolerance (Table 4). The second part focused directly on CSR issues. The respondents 
were asked to indicate their individual (here: subjective) understanding of the concept of CSR (Corporate Social Responsibility). Students had a choice of four different definitions, but it was also possible to formulate their own definition which, in their opinion, reflects the knowledge of the respondents as far as possible. An option was also introduced which enabled the indication of a lack of knowledge in the field of CSR.

The HEI's obligation to transfer knowledge, as well as to shape civic attitudes and participate in social development, were the factors which determined the introduction of the student self-assessment module in the research concerning the implementation of learning outcomes in the field of responsibility of a contemporary HEI. On a 5-point scale (where 1 was the lowest rating, and 5 the highest), the respondents commented on the issue of their own development during the study. The respondents noted the greatest progress in their area of knowledge (where less than $44 \%$ of the respondents chose 4) and tolerance (where nearly $30 \%$ of students chose 4 , and a group smaller by $3 \%$ selected the highest rating - 5). The respondents indicated an average level of development (3) for general knowledge (nearly $40 \%$ of responses), while also rating the level of empathy and sensitivity to social problems (nearly $31 \%$ of responses) and the level of knowledge of responsible consumption (about 30\% of responses) not as highly as it could be. When taking into account the highest percentage of responses in the rating, it turns out that sensitivity to social problems and market responsibility were rated poorly (1); the second of these categories was rated slightly better (2); most indications for the satisfactory rating (3) were for general knowledge; knowledge related to the respondents' field of study was positively rated (4) and tolerance was rated the highest. Averaging the ratings indicated by students in the five categories analyzed, it should be emphasized that the overall rating expressed by the weighted average rating indicator does not exceed the average level.

When analyzing the average ratings, a trend is visible in which student ratings are in a range between $36 \%$ and $58.6 \%$ of the maximum. A low level of knowledge and/or development is observed in the last two categories, namely sensitivity to social problems and knowledge of responsible consumption. The level of general knowledge, which may be classified as unsatisfactory, is slightly better in the average rating. The highest level observed was in the case of tolerance and field-related knowledge. 


\section{Table 4. Students' self-assessment}

\begin{tabular}{|c|c|c|c|c|c|c|c|}
\hline & $\begin{array}{c}1(\text { in } \%) \\
\text { unsatisfactory } \\
\text { rating }\end{array}$ & $\begin{array}{c}2 \text { (in \%) } \\
\text { poor } \\
\text { rating }\end{array}$ & $\begin{array}{c}\text { 3(in \%) } \\
\text { satisfactory } \\
\text { rating }\end{array}$ & $\begin{array}{l}4(\text { in } \%) \\
\text { good } \\
\text { rating }\end{array}$ & $\begin{array}{c}5(\mathrm{in} \%) \\
\text { very } \\
\text { good rating }\end{array}$ & $\begin{array}{l}\text { Weighted average } \\
\text { mean indicator } \\
(\text { max value }-500)\end{array}$ & $\begin{array}{c}\text { Percentage } \\
\text { share of the } \\
\text { indicatorin } \\
\text { the max. value } \\
\text { of the scale }\end{array}$ \\
\hline Tolerance & 12.4 & 15.5 & 16.1 & 29.8 & 26.1 & 293.1 & $\begin{array}{c}58.6 \% \\
\text { (medium level) }\end{array}$ \\
\hline Field-related knowledge & 1.9 & 10.5 & 25.9 & 43.8 & 17.9 & 287.6 & $\begin{array}{c}57.5 \% \\
\text { (medium level) }\end{array}$ \\
\hline General knowledge & 4.9 & 11.1 & 39.5 & 32.1 & 12.3 & 217.0 & $\begin{array}{c}43.4 \% \\
\text { (unsatisfactory } \\
\text { level) }\end{array}$ \\
\hline $\begin{array}{l}\text { Sensitivity to social } \\
\text { problems }\end{array}$ & 16.0 & 25.3 & 30.9 & 14.2 & 13.6 & 191.4 & $\begin{array}{c}38.3 \% \\
\text { (low level) }\end{array}$ \\
\hline $\begin{array}{l}\text { Knowledge of responsible } \\
\text { consumption }\end{array}$ & 16.0 & 29.0 & 30.2 & 17.3 & 7.4 & 180.2 & $\begin{array}{c}36.0 \% \\
\text { (low level) }\end{array}$ \\
\hline
\end{tabular}

KEY:

— the highest percentage of responses in a given category which is subject to assessment;

- the highest percentage of responses at each level of rating from 1 to 5 .

Source: own study.

From the point of view of the adopted research goal and verification of the hypothesis, it is important to check whether the result obtained in the category "Students' knowledge of responsible consumption" differed depending on the group of students surveyed. To this end, two hypotheses were formulated: $\mathrm{H}_{0}$ saying that the result does not depend on the group, i.e. the results come from a distribution with the same average, and an alternate hypothesis (which will be proven) saying that the results depend on the students' field of study, and therefore the results obtained among students in various fields come from distributions with different averages. To verify the hypotheses, a one-way ANOVA analysis of variance was used; this was preceded by checking the assumptions regarding the distribution 
of results in each group and assumptions about homogeneity of intra-group variance. The first assumption was verified by performing the KolmogorovSmirnov test for one sample (Table 5).

\section{Table 5. Kolmogorov-Smirnov test for one sample} (regarding the level of knowledge of responsible consumption)

\begin{tabular}{l|c|c}
\hline & N & $\mathbf{1 6 2}$ \\
\hline Normal distribution parameters a,b & Mean & 2.710 \\
& Standard deviation & 1.151 \\
Largest differences & Absolute value & 0.182 \\
& Positive & 0.182 \\
& Negative & -0.149 \\
Test statistics & & $\mathbf{0 . 1 8 2}$ \\
Asymptotic (two-sided) significance & & $\mathbf{. 0 0 0}^{\mathbf{c}}$ \\
\hline
\end{tabular}

\footnotetext{
a Test distribution in Normal.

${ }^{\mathrm{b}}$ Calculated from data.

${ }^{\mathrm{c}}$ Lillefors Significance Correction.
}

Source: own study.

The average self-assessment of students in terms of their knowledge of responsible consumption was 2.71 , and the so-called average dispersion of assessments of the degree of HEI involvement indicates that the ratings are separated on average by about 1.15 from the arithmetic mean. The result of asymptotic significance obtained in the test is less than 0.05 , which gives grounds for rejecting the null hypothesis and the statement that the tested distribution is not normal. Due to the fact that analysis of variance is relatively robust to departures from normality of distribution, the obtained result is not an obstacle in terms of the ANOVA analysis.

The analysis procedure began with checking the assumption of homogeneity of intra-group variance (Table 6) and performing the Levene test (Table 7). The highest average degree of the assessment of students' knowledge of responsible consumption was recorded in the case of respondents representing medical faculties (3.20); in this group, differences in results were also the smallest, compared to the average rating $(0.45-$ standard deviation). The respondents from this group gave only ratings of 
3 and 4. The lowest average rating of the level of knowledge was observed among students in language studies (2.29). The ratings given by these respondents were the lowest (1) and the highest (5).

\section{Table 6. Descriptive statistics for the question regarding the level of knowledge of responsible consumption}

\begin{tabular}{|c|c|c|c|c|c|c|c|c|}
\hline \multirow{2}{*}{ Detailed list } & \multirow{2}{*}{$\mathbf{N}$} & \multirow{2}{*}{ Mean } & \multirow{2}{*}{$\begin{array}{l}\text { Standard } \\
\text { Deviation }\end{array}$} & \multirow{2}{*}{$\begin{array}{l}\text { Standard } \\
\text { Error }\end{array}$} & \multicolumn{2}{|c|}{$\begin{array}{l}\text { 95\% Confidence } \\
\text { Interval for Mean }\end{array}$} & \multirow{2}{*}{ Minimum } & \multirow{2}{*}{ Maximum } \\
\hline & & & & & $\begin{array}{l}\text { Lower } \\
\text { Bound }\end{array}$ & $\begin{array}{l}\text { Upper } \\
\text { Bound }\end{array}$ & & \\
\hline $\begin{array}{l}\text { Business and } \\
\text { administration } \\
\text { subgroup }\end{array}$ & 84 & 2.75 & 1.171 & 0.128 & 2.50 & 3.00 & 1 & 5 \\
\hline $\begin{array}{l}\text { Engineering and } \\
\text { technical subgroup }\end{array}$ & 14 & 2.79 & 0.975 & 0.261 & 2.22 & 3.35 & 1 & 4 \\
\hline Medical subgroup & 5 & 3.20 & 0.447 & 0.200 & 2.64 & 3.76 & 3 & 4 \\
\hline Social subgroup & 19 & 2.47 & 1.307 & 0.300 & 1.84 & 3.10 & 1 & 5 \\
\hline Pedagogical subgroup & 8 & 3.00 & 1.309 & 0.463 & 1.91 & 4.09 & 1 & 5 \\
\hline Language subgroup & 14 & 2.29 & 1.139 & 0.304 & 1.63 & 2.94 & 1 & 5 \\
\hline Other & 18 & 2.78 & 1.114 & 0.263 & 2.22 & 3.33 & 1 & 5 \\
\hline Total & 162 & 2.71 & 1.151 & 0.090 & 2.53 & 2.89 & 1 & 5 \\
\hline
\end{tabular}

Source: own study.

In the Levene's test for the homogeneity of variances (Table 5d), the following pair of hypotheses was used: $\mathrm{H}_{0}$ - the difference between variances in the groups studied is homogeneous (or similar), $\mathrm{H}_{1}$ - the variances in the groups studied are different. The Levene F value (6.155) is 1.27. In turn, the significance calculated for Levene's test is higher than 0.05 , and therefore there is no reason to reject $\mathrm{H} 0$, so the variance is assumed to be homogeneous. Therefore, the alternate hypothesis was rejected and the null hypothesis saying that the difference in variance in the groups studied was statistically insignificant was adopted. 


\section{Table 7. Test of the homogeneity of variance for the question regarding the level of knowledge of responsible consumption}

\begin{tabular}{l|c|c|c|c|c}
\hline \multicolumn{2}{c|}{ Detailed list } & Levene's test & df1 & df2 & Significance \\
\hline $\begin{array}{l}\text { Knowledge of } \\
\text { responsible consumption }\end{array}$ & $\begin{array}{l}\text { Based on } \\
\text { the mean }\end{array}$ & 1.270 & 6 & 155 & 0.274 \\
\hline
\end{tabular}

Source: own study.

After verifying all assumptions, the ANOVA analysis of variance was performed (Table 8). Significance for the F-statistic $(6,155)=0.716$, while the indicated number of degrees of freedom ( $\mathrm{df}$ ) is 0.637 , which gives the basis for adopting the null hypothesis, and thus for concluding that the differences in the results obtained in different groups of students are not statistically significant, and that the field of study is not a factor which affects the assessment of students' knowledge. It is worth emphasizing that two fields of study, namely medical and pedagogical, are underrepresented in the sample, which should be considered at the hypothesis testing stage.

\section{Table 8. One-way ANOVA analysis of variance for the level} of knowledge of responsible consumption

\begin{tabular}{l|c|r|c|c|c}
\hline \multicolumn{1}{c|}{ Detailed list } & Sum of squares & \multicolumn{1}{c|}{ df } & Mean square & F & Significance \\
\hline Between groups & 5.752 & 6 & 0.959 & 0.716 & 0.637 \\
Inside groups & 207.612 & 155 & 1.339 & & \\
Total & 213.364 & 161 & & & \\
\hline
\end{tabular}

Source: own study.

The subsequent stage of research focused on gaining knowledge of the actual understanding of the conceptual construct of CSR. Nobody decided to give their own definition, and 22 people admitted their ignorance in this respect. The definitions given in the set of questions include those that have some connection with the above-mentioned concept (an incomplete definition), discuss the essence of the concept or represent its complete negation. Over half the respondents defined CSR correctly. A significant group of people selected options that relate to the implementation of this concept. 
Considering the fact that selecting the correct definition could have been the result of logical thinking, by accident or the use of an elimination strategy, at the next stage of the research the respondents were asked to share information on the source of their knowledge of CSR. It turns out that universities implement CSR in the educational process. Over $38 \%$ of students admitted that they acquired knowledge of social responsibility during classes and lectures. Less than $5 \%$ of students stood in opposition, believing that the obligation to acquire knowledge "of global problems" lies with the student himself or herself, not the HEI, and the former should actively seek information about CSR. These students attributed a large role in the consumer education process to the media.

The obtained data is rich material that has contributed to increasing the level of knowledge of the use of the concept of SR by Polish HEIs, and additionally contributes to further, more detailed exploration in this field.

\section{Conclusions and further context}

In the course of the questionnaire research, students' information on the concept of the USR, including the degree of its implementation, was obtained. The results gave grounds for confirming the statement that the degree of involvement of respondents' HEIs in the implementation of tasks in the area of social responsibility is unsatisfactory. A group of over $84 \%$ gave responses which, according to the assumptions of the research, meant that the level of activities undertaken by HEIs was unsatisfactory. For example a group of $30 \%$ who marked at a maximum of 2 in the scale (what meant - medium involvement) and a group of over $27 \%$ marked of 3 in the scale (what meant medium involvement). The obtained results were further tested, in which it turned out that the opinion on the degree of implementation of the concept of social responsibility by universities is not determined by the respondent's field of study. The study assumed that the opinion may also result from the students' knowledge (or lack of knowledge) in the field of social responsibility or responsible consumption. Students made self-assessment in the indicated areas. The analysis of the results showed that the degree to which students are familiar with the issue of social responsibility is negligible and thus another of the verified 
hypotheses was confirmed. Nearly $47 \%$ of the respondents admitted that their understanding of the concept of CSR is intuitive in their case, although a conceptual construct was defined correctly in most cases. In addition, when self-assessing their knowledge of responsible consumption, among others, the respondents were critical of themselves. Three-quarters of respondents rated their level of awareness as no higher than satisfactory (3 on a 5-point scale). The statement about the existence of relationships between the self-assessments of the respondents and their field of study was also verified. As in the previous case, analyses showed that the differences in the results obtained for different groups are statistically insignificant. Students' knowledge of social responsibility can be considered insufficient, which can be proved by the low percentage of indications for good and very good ratings during student self-assessment, among others. Despite the fact that most of the concepts related to the research subject were defined correctly, a large proportion of respondents admitted to their intuitive understanding. Only a group constituting $38.1 \%$ of all respondents who gained knowledge during didactic classes, which is a significant symptom of the HEI fulfilling its voluntarily accepted obligation to educate aware citizens.

The growing interest of HEIs in the concept of social responsibility has not yet translated into its widespread and full implementation; nevertheless, the very positioning of HEIs as socially responsible was an incentive to undertake research that focused on finding an answer to the question: does the creation of an image of HEIs which adapts the academic version of the concept of CSR, known as USR, translate into its implementation in the form of specific actions assigned to the concept. And as a result, it is possible to identify the determinants of the implementation of the concept of USR in the context of its market functioning and voluntarily accepted obligation to educate in the field of conscious consumption and sustainable development, among others.

The research results constitute the first stage of data acquisition in the area of corporate social responsibility of HEIs in Poland. The research was exploratory, which made it possible to obtain basic information on the involvement of Polish HEIs in the implementation of the concept of USR and identify the level of students' knowledge of social issues. In the context of the results obtained, as well as the insufficient operability of HEIs and 
the low level of students' knowledge, it is necessary to identify factors determining the current state. It is also important to extend the scope of the research, i.e. to obtain data not only from students (as was the case in the scope of this research), but also from other groups of stakeholders and people responsible for HEI management.

The main problem to be faced when conducting research in the higher education sector is the complexity of the research process, which consists of several factors. First of all, there is no sampling frame of the population studied, which applies in particular to students and partly to research and teaching staff. HEIs rarely want to participate in the process of distributing invitations to take part in the study (as was the case with the research into market orientation conducted by the author). In addition, companies that are HEI stakeholders rarely participate in the study, justifying it by citing a lack of resources and time. The analyzed problem and subject scope determine the use of various test methods and sample selection methods, which can facilitate data collection.

The referred study has some limitations, one of which is limiting the analysis only to a small group of Silesian students and obtaining opinions from only one group of university stakeholders. This, however, did not hinder the achievement of the research goal and allowed for a preliminary diagnosis of the higher education sector in the context of USR; thus, the study is an introduction to further exploration in this area. Another limitation is the use of mainly qualitative data obtained on the basis of student feedback. A limitation may also be the sample itself, in which two fields of study were not adequately represented in sufficiently large numbers.

The presented research results are important because they indicate deficits in the field of USR in Poland. The completed research project is one of the few studies of this type on this market and the thing worth emphasizing is that presented study is only illustrative material and it is an introduction to the implementation of a wider research, carried out on a larger research sample. Nevertheless, the information obtained may also be taken into account by HEIs operating in other markets and attempting to orientate themselves socially and intensify their actions in the field of ethical and environmental problems, etc. The results achieved may be a reliable indicator of which areas should be modified and which areas should be studied in more detail, regardless of university location. 


\section{Endnotes}

* In the article there are used abbreviations for the following conceptual constructs: Higher Education Institutions (HEIs); Social Responsibility (SR) University Social Responsibility (USR). In the remainder of the text, the abbreviations HEIs, SR and USR will be used instead of their full-text equivalents.

** Sample documents regulated the standard of SR:

1. A renewed EU strategy 2011-14 for corporate social responsibility. Available online: https://eurlex.europa.eu/legal-content/EN/TXT/?uri=CELEX:52011DC0681 (accessed on 12th August 2019).

2. DIRECTIVE 2014/95/EU OF THE EUROPEAN PARLIAMENT AND OF THE COUNCIL of 22 October 2014 amending Directive 2013/34/EU as regards disclosure of non-financial and diversity information by certain large undertakings and groups. Available online: https://eur-lex.europa.eu/legal-content/EN/TXT/?uri=CELEX\%3A32014L0095 (accessed on 12th August 2019).

3. United Nations global compact. Available online: https://www.unglobalcompact.org/ (accessed on 12th August 2019).

4. OECD DUE DILIGENCE GUIDANCE FOR RESPONSIBLE BUSINESS CONDUCT. Available online: http://mneguidelines.oecd.org/OECD-Due-Diligence-Guidance-for-Responsible-Business-Conduct.pdf (accessed on 12th August 2019).

5. Action Plan on Human Rights and Democracy (2015-2019). Available online: https://ec.europa.eu/antitrafficking/eu-policy/action-plan-human-rights-and-democracy-2015-2019_en (accessed on 12th August 2019).

6. COMMUNICATION FROM THE COMMISSION TO THE EUROPEAN PARLIAMENT, THE COUNCIL, THE EUROPEAN ECONOMIC AND SOCIAL COMMITTEE AND THE COMMITTEE OF THE REGIONS. Available online: https:/ec.europa.eu/europeaid/sites/devco/files/communication-next-steps-sustainable-europe20161122_en.pdf (accessed on 12th August 2019).

7. A Sustainable Europe by 2030. Available online: https://ec.europa.eu/commission/publications/reflectionpaper-towards-sustainable-europe-2030_en (accessed on 12th August 2019).

8. Guiding Principles on Business and Human Rights. Implementing the United Nations "Protect, Respect and Remedy" Framework. Available online: https://www.ohchr.org/Documents/Publications/GuidingPrinciples BusinessHR_EN.pdf (accessed on 12th August 2019).

9. Guidelines for multinational enterprises. Available online: http://www.oecd.org/corporate/mne/ (accessed on 12th August 2019).

10. ISO 26000 SOCIAL RESPONSIBILITY. Available online: https://www.iso.org/iso-26000-social-responsibility.html (accessed on 12th August 2019).

11. The Sustainable Development Agenda. Available online: https://www.un.org/sustainabledevelopment/development-agenda/ (accessed on 12th August 2019).

*** More about researches on USR:

1. Ahmad, J. (2012). Can university act as a corporate social responsibility (CSR) driver? An analysis. Social Responsibility Journal, 8, 77-86. https://doi.org/10.1108/17471111211196584.

2. Alcota, M., Ruiz de Gauna, P., \& González, F.E. (2013). Development of ethical practices and social responsibility in dental education at the university of Chile: Student and faculty perceptions. European Journal of Dental Education, 17, 70-76. https://doi.org/10.1111/j.1600-0579.2012.00767.x.

3. Dima, A. M., Vasilache, S., Ghinea, V., \& Agoston, S. (2013). A model of academic social responsibility. Transylvanian Review of Administrative Sciences, 9, 23-43. https://www.researchgate.net/publication/ 281320388_A_model_of_academic_social_responsibility.

4. Tauginiene, L., \& Maèiukaite-Žviniene, S. (2013). Managing University Social Responsibility. IOSR Journal of Humanities and Social Science, 13(4), 84-91. http://www.iosrjournals.org/iosr-jhss/papers/Vol13issue4/001348491.pdf?id=3407.

5. Karimi, M.R. (2013). Designing the conceptual model of social responsibility of the Azad University by public relation role. African Journal of Business Management, Vol. 7(1), 8-21.

6. Gomez, L. (2014). The importance of university social responsibility in Hispanic America: A responsible trend in developing countries. Critical Studies on Corporate Responsibility, Governance and Sustainability, 8, 241-268. https://doi.org/10.1108/S2043-905920140000008013.

7. Nejati, M., Shafaei, A., Salamzadeh, Y., \& Daraei, M. (2011). Corporate social responsibility and universities: A study of top 10 world universities' websites. African Journal of Business Management, 5(2), 440-447. https://www.academia.edu/954861/Corporate_social_responsibility_and_universities_A_study_of_top_10_world_ universities_websites. 


\section{References}

1. Alzyoud, S.A., \& Bani-Hani, K. (2015). Social responsibility in higher education institutions: Application case from the Middle East. European Scientific Journal, 11(8), 122-129. https://eujournal.org/index.php/esj/article/view/5259.

2. Babbie, E.R. (1990). Survey research methods. Wadsworth Publishing Company: Belmonton.

3. Buchat, K., Jakubiak, M., Skiert, M., \& Wilczewski, A. (2018). University's social responsibility - labour market perspective. Folia Oeconomica Stetinensia, 18(2), 46-48. https://doi.org/10.2478/foli-2018-0018.

4. Carroll, A. B. (1976). A three-dimensional conceptual model of corporate performance. The Academy of Management Review, 4(4), 497-505. https://doi.org/10.2307/257850.

5. Commission of the European Communities. (2001, July 19). Green Paper: Promoting a European framework for Corporate Social Responsibility, p. 19. https://ec.europa.eu/ commission/presscorner/detail/en/DOC_01_9 (accessed on 16th August 2019).

6. Cornelius, N., Wallace, J., \& Tassabehji, R. (2007). An analysis of corporate social responsibility, corporate identity and ethics teaching in business schools. Journal of Business Ethics, 76, 117-135. https://doi.org/10.1007/s10551-006-9271-6.

7. Crowther, D., \& Aras, G. (2008). Corporate social responsibility. Ventus Publishing ApS: Denmark. https://archive.org/details/CorporateSocialResponsibility/page/n1. (accessed 5th September 2019).

8. CSR - Finance Institute. (n.d.). H-CSR-M: Hopkins CSR/Sustainability Model: Rapid CSR/Sustainability reporting with H-CSR-M. https://www.csrfi.com/hopkinscsrmodel. (accessed on 5th September 2019).

9. Cygler, J., Sroka, W., Solesvik, M., \& Dębkowska, K. (2018). Benefits and drawbacks of coopetition: The role of scope and durability in coopetitive relationships. Sustainability, 10(8), 1-12. https://doi.org/10.3390/su10082688.

10. Dahlsrud, A. (2008). How corporate social responsibility is defined: An analysis of 37 definitions. Corporate Social Responsibility and Environmental Management 15, 1-13. https://doi.org/10.1002/csr.132.

11. Fundacja Rektorów Polskich. (2007). Kodeks "Dobre praktyki w szkołach wyższych.". Konferencja Rektorów Akademickich Szkół Polskich \& Fundacja Rektorów Polskich: Kraków, Poland, 1-16. https://arch.krasp.org.pl/pl/kdp/kodeks_dobre_praktyki. (accessed on 16th August 2019).

12. Giuffre, L., \& Ratto, S.E. (2014, March). A new paradigm in higher education: University social responsibility (USR). Journal of Education \& Human Development 3(1), 231-238. http://jehdnet.com/vol-3-no-1-march-2014-abstract-15-jehd.

13. Gourova, E., Todorova, Y., \& Gourov, N. (2009). Skills for future engineers: Challenges for universities in Bulgaria. WSEAS Transactions on Business and Economics, 6, 385-399. https://www.academia.edu/25220889/Skills_for_future_engineers_challenges for_universities_in_Bulgaria.

14. Hamidu, A.A., Haron, H.M., \& Amran, A. (2015). Corporate social responsibility: A review on definitions, core characteristics and theoretical perspectives. Mediterranean Journal of Social Science, 6, 83-95. http://dx.doi.org/10.5901/mjss.2015.v6n4p83. 
15. Ibom, A., \& Akpan, U. (2014). The survey communication research. International Journal of Education and Research 2(10), 461-478. https://www.ijern.com/ journal/2014/October-2014/36.pdf.

16. KRASP. (2019). Deklaracja Spotecznej Odpowiedzialności Uczelni. https://www.krasp.org.pl/resources/upload/dokumenty/prezentacje/UWMOlsztyn/P711dok15_Spoleczna_Odpowiedzialnosc_Uczelni.pdf (accessed on 11th August 2019).

17. Konferencja Rektorów Akademickich Szkót Polskich /KRASP/ (2019). https://www.krasp.org.pl/pl/Aktualnosci/?id=20530/KRASP_wsrod_sygnatariuszy_dekla racji_(accessed on 16th August 2019).

18. Pabian, A. (2016). Od konwergencji sektorów poprzez konkurencję wśród polskich uczelni publicznych i niepublicznych po rozwiązania hybrydowe. Marketing $i$ Rynek, 4 , 2-10.

19. Pabian A. (2016). Rynkowa orientacja szkót wyższych w Polsce - uwarunkowania, wyznaczniki, prawidtowości. Wydawnictwo Wyższej Szkoły Biznesu w Dąbrowie Górniczej: Dąbrowa Górnicza, Poland; 93-163.

20. Pabian, A.M. (2019). University social responsibility in the opinion of students. Forum Scientiae Oeconomia, 7(4), 101-117. DOI: 10.23762/FSO_VOL7_NO4_7.

21. Pędziwiatr, E., Czaplicka-Kotas, A., \& Kulczycka, J. (2018). Działania realizowane przez szkoły wyższe w ramach społecznej odpowiedzialności - dobre praktyki. Ekonomika Społeczna, 1, 45-56. https://www.researchgate.net/deref/http\%3A\%2F\%2Fdx.doi.org\% 2F10.15678\%2FES.2018.1.04.

22. Sawasdikosol, S. /P. Moral/ (2009). Driving universities' collaboration toward the new era of sustainable social responsibility. Presented at the University-Community Engagement Conference, 23-26 November 2009, Penang, Malaysia. http://www.globalusrnetwork.org/ resources/Driving_Universities.pdf (accessed on 3rd September 2019).

23. Statistics Poland, Statistical O?ce in Gdańsk. (2018). Higher education institutions and their finances in 2017; Statistics Poland, Statistical O?ce in Gdańsk: Warszawa, Gdańsk, Poland, 299-320.

24. Tetřevová, L., \& Sabolová, V. (2010). University Stakeholder Management and University Social Responsibility. WSEAS transactions on advances in engineering education, 7(7), 224-233. http://www.wseas.us/e-library/transactions/education/2010/88-330.pdf.

25. European University Association. (2007, April 13). The Lisbon Declaration. Europe's Universities beyond 2010: Diversity with a Common Purpose. https://bmbwf.gv.at/fileadmin/ user_upload/Bologna_Grundsatzdok/Von_Bergen_bis_London/EUA_Lisbon_declaration _Mai_07.pdf (accessed on 15th August 2019).

26. Tien, H.T. (2014). What is the difference between $\operatorname{CSR}_{1}, \mathrm{CSR}_{2}, \mathrm{CSR}_{3}$ and $\mathrm{CSR}_{4}$ ? https://www.researchgate.net/publication/261133486_What_is_the_difference_between_ CSR1_CSR2_CSR3_and_CSR4 (accessed on 5th September 2019).

27. Universities for Enlightenment. (2018, December 13). http://www.rkrs.si/gradiva/ Dokumenti_RKRS/Priloga_k_sklepu_S22_joint_statement_ORIGINAL.PDF (accessed on 16th August 2019).

28. Vallaeys, F. (2018). Defining social responsibility: A matter of philosophical urgency for universities. The Global University Network for Innovation. http:/www.guninetwork.org/ articles/defining-social-responsibility-matter-philosophical-urgency-universities (accessed on 14th August 2019). 
29. Vasilescu, R., Barna, C., Epure, M., \& Baicu, C. (2010). Developing university social responsibility: A model for the challenges of the new civil society. Procedia - Social and Behavioral Sciences, 2(2), 4177-4182. https://doi.org/10.1016/j.sbspro.2010.03.660.

30. European Commission. (2017, March 1). White paper on the future of Europe: Reflections and scenarios for the EU27 by 2025, p. 10. https://ec.europa.eu/commission/ sites/beta-political/files/white_paper_on_the_future_of_europe_en.pdf (accessed on 16th August 2019).

Angelika M. Pabian - Angelika M. Pabian - PhD in economic sciences in the discipline of management science, Assistant Professor at the Faculty of Social Sciences of the University of Silesia in Katowice. Academic lecturer conducting workshops, courses and trainings dedicated not only to students, i.e. CRM, IT tools in data analysis or Marketing in a non-standard edition. Scientific interests: marketing management with particular emphasis on marketing communications of non-profit organisations. She specializes in the subject of market orientation of universities. 